\section{AGRIEKONOMIKA}

http://journal.trunojoyo.ac.id/agriekonomika

Volume 10, Nomor 1, 2021

https://doi.org/10.21107/agriekonomika.v10i1.9391
Agriekonomika has been accredited as a scientific journal by the Ministry of

Research-Technology and Higher

Education Republic of Indonesia: No.

23/E/KPT/2019

\title{
Strategi Peningkatan Kesejahteraan Petani Indonesia, Review Manajemen Strategis
}

\author{
$凶 1,2$ Leny Marita, ${ }^{3}$ Mohammad Arief, ${ }^{3}$ Nurita Andriani, ${ }^{3}$ Muhammad Alkirom Wildan3 \\ ${ }^{1}$ Sekretariat Daerah Kab. Bangkalan, Indonesia \\ ${ }^{2}$ Pasca Sarjana Magister Manajemen, Universitas Trunojoyo Madura, Indonesia \\ ${ }^{3}$ Fakultas Ekonomi dan Bisnis, Universitas Trunojoyo Madura, Indonesia
}

Received: Januari 2021; Accepted: April 2021; Published: April 2021

\begin{abstract}
ABSTRAK
Penelitian ini bertujuan membangun kerangka strategi peningkatan kesejahteraan petani, terkait kondisi petani, stakeholder pertanian, strategi yang dilakukan, dan ukuran kinerja, untuk memberikan gambaran trend manajemen strategis dalam peningkatan kesejahteraan petani. Penelitian ini mengandalkan studi pustaka dari artikel tentang aspek sosioekonomi dan kebijakan pertanian di Indonesia. Kelembagaan, tata niaga, produksi pertanian, kebutuhan komoditas pertanian, regulasi pertanian, keuangan, manajemen risiko, demografi sosial, teknologi pertanian, ekologi, adalah kondisi yang mempengaruhi kesejahteraan petani Indonesia. Strategi penguatan kesejahteraan petani yang teridentifikasi adalah: intensifikasi, ekstensifikasi, diversifikasi usaha, manajemen pemasaran dan rantai pasok, kemitraan dan kelembagaan, adopsi teknologi, manajemen risiko dan keuangan. Penerapan strategi ini memerlukan sinergi stakeholder pertanian: pemerintahan pusat dan daerah, industri, pedagang komoditas, lembaga keuangan, koperasi dan lembaga tani. Ukuran kinerja dari strategi-strategi ini adalah: peningkatan produktifitas, pengurangan biaya, perbaikan kualitas produk, akses pasar lebih luas, kestabilan keuangan, perlindungan risiko, kondisi kerja lebih baik, diferensiasi sumber penghasilan, dan kelestarian lingkungan.
\end{abstract}

Kata kunci: Strategi Pertanian, Stakeholder Pertanian, Kinerja Pertanian.

Strategies for Empowering the Welfare of Indonesian Farmers, a Review of Strategic Management Approaches

\section{ABSTRACT}

This study aims to build a framework for Indonesian farmer welfare empowerment strategies related to the farmer condition, agricultural stakeholders, strategies implemented, and performance measures; to provide an overview of strategic management trends in raising farmer welfare. The research relies on literature studies from articles that address agricultural socioeconomics and policy in Indonesia. Problems concerning the Indonesian farmer welfare consist of agriculture institutions, business systems, agricultural production, commodities demand, agricultural regulations, finance risk, social demographics, agricultural technology, and environmental issue. The strategies identified: agriculture intensification, agriculture expansion, business diversification, marketing, supply chain management, partnerships, institutions empowerment, risk management, and adoption of technology. Implementing these strategies requires the synergy of stakeholders: government, industry, commodity traders, farmer associations, financial institutions. The performance measures of these strategies: increased productivity, reduced costs, improved product quality, broader market access, financial stability, asset and risk protection, better working conditions, differentiation of income sources, environmental sustainability.

Keyword: Empowerment, Urban Farming, SEM-PLS, Food Security 


\section{PENDAHULUAN}

Pertanian ialah kegiatan bercocok tanam, peternakan, perikanan, perkebunan, kehutanan, pengolahan dan pemasaran hasil bumi (Kusmiadi, 2014). Secara global, peran pertanian mendapat tekanan besar karena tuntutan menyediakan kebutuhan pangan bagi populasi yang terus bertambah. Oleh sebab itu, peranan pertanian dan industri manufaktur menentukan kekuatan suatu negara (Barnett \& Hansen, 1996), sehingga sistem manajemen bisnis pertanian harus mendapat prioritas (Ommani, 2011). Nielsen (1988), memberikan contoh manajemen strategis secara kooperatif, bagaimana sebuah perusahaan pemasaran buah, Ocean Spray Cranberries, dibangun dengan kemitraan bersama komunitas petani buah lokal. Perusahaan ini berhasil memasarkan buah hasil produksi para petani lokal dari yang sebelumnya hanya mampu menjual satu juta dollar pada tahun 1930, kemudian mampu menembus pasar nasional dengan penjualan 500 juta dollar pada tahun 1985. Untuk memenangkan pasar diperlukan keunggulan bersaing, memberikan nilai lebih pada produk pertanian, biaya produksi rendah, fokus pada strategi keberhasilan, kemampuan bertahan pada kondisi buruk (Rumelt \& Kunin, 2003).

Pertanian juga menghadapi risiko ketidak-pastian kompetisi sumber daya alam, kelestarian alam, ketidak-pastian demand industri, sehingga membentuk kondisi keseimbangan dinamis (Lippman \& Rumelt, 1982; Lippman \& Rumelt, 1992). Produk pertanian pada akhirnya menjadi barang konsumsi dan melalui lintasan pengepul, industri, distributor, pengecer. Keberagaman kualitas produk pertanian yang menjadi bahan baku industri, dan karakteristik pembelian konsumen menjadi faktor penting dalam persaingan industri (Michael E. Porter, 1974). Keterkaitan faktor keberagaman kualitas bahan baku, dan karakteristik pembelian konsumen yang menjadi faktor penting dalam persaingan industri mampu ditransformasikan menjadi strategi CSR
(Corporate Social Responsibility) oleh (McWilliams \& Siegel, 2001). McWilliams \& Siegel (2001), memberikan contoh bagaimana McDonald's bermitra dengan petani untuk memasok bahan makanan bermutu sekaligus menjadikan kemitraan ini sebagai media periklanan yang menunjukan penjaminan kualitas produk yang dilakukan McDonald's.McWilliams \& Siegel (2001), juga mengidentifikasi peluang CSR sebagai strategi diferensiasi perusahaan. Diantara strategi diferensiasi dengan melakukan inovasi nilai baru bagi pertanian adalah mengembangkan pertanian sebagai agriwisata. Zehrer (2009), menyarankan kerja sama sinergis antar wilayah penyedia wisata yang secara tradisional terfragmentasi, untuk mencapai daya saing jangka panjang.

Selain permasalah global tersebut, pertanian di Indonesia dihadapkan pada rendahnya tingkat kesejahteraan petani, masalah pemodalan, akses ke lembaga pembiayaan, akses pasar, daya saing, kekuatan hukum dan sosial, kelestarian lingkungan (Nuswardani, 2019). Foss (1997), menyarankan sinergi kemampuan internal dengan peran pemerintah untuk meningkatkan daya saing. Pemerintah dalam hal ini juga sebagai stakeholder pertanian Indonesia bersama industri, pedagang, koperasi, asosiasi, kelompok tani, dan lembaga keuangan (Nuraini \& Atmaja, 2019). Peningkatan kesejahteraan petani juga menjadi target sasaran yang hendak dicapai oleh Kementrian Pertanian tahun 2014 (Watemin \& Sulistyani, 2015).

\section{METODE PENELITIAN}

Penelitian ini bertujuan membangun kerangka kerja konsep analisis strategi pemberdayaan kesejahteraan petani dengan merujuk pada model kanvas yang dibangun oleh Grando dkk. (2016), terkait dengan kondisi petani, strategi yang dilakukan, dan ukuran kinerja. Penulis menambahkan stake holder pertanian Indonesia dalam model kanvas Grando. Penelitian kualitatif ini mengandalkan studi literatur dari beragam artikel ilmiah oleh peneliti yang tersebar di beberapa wilayah 
Indonesia yang membahas tentang aspek ekonomi pertanian, sosiologi pertanian, kebijakan pertanian di Indonesia. Pencarian artikel jurnal dilakukan menggunakan portal GARUDA RISTEKBRIN (https://garuda. ristekbrin.go.id), kata kunci "kesejahteraan petani" dan "strategi pertanian" pada periode tahun 2000 hingga tahun 2020.

\section{HASIL DAN PEMBAHASAN}

Sesuai dengan model kanvas Grando dkk. (2016), kelembagaan, tata niaga, produksi pertanian, kebutuhan komoditas pertanian, regulasi kebijakan pertanian, keuangan, manajemen risiko, demografi sosial, teknologi pertanian, ekologi lingkungan, adalah kondisi umum yang mempengaruhi kesejahteraan petani (Tabel 1). Kondisikondisi ini tidak berdiri sendiri masingmasing, namun saling terkait. Gambaran kondisi-kondisi tersebut akan dibahas dalam bagian-bagian berikut ini.

\section{Kondisi yang Mempengaruhi Ke- sejahteraan Petani Indonesia SDM Petani dan Kelembagaan}

Kelembagaan merupakan perangkat aturan yang dikenali, diikuti dan dijalankan oleh masyarakat, dengan memberi wadah bagi anggota masyarakat (Santoso \& Darwanto, 2015). Kelembagaan Petani merupakan lembaga yang dikembangkan dari petani, oleh petani, dan untuk petani dengan tujuan memperkuat petani dan membela kepentingan petani, termasuk Kelompok Tani, Gabungan Kelompok Tani, Dewan Komoditas Pertanian Nasional dan Asosiasi Komoditas Pertanian, sesuai Peraturan Menteri Pertanian Republik Indonesia Nomor 67/ PERMENTAN/SM.050/12/2016 tentang Pembinaan Kelembagaan Petani, (2016). Kelembagaan petani diperlukan dalam mengelola aktifitas pertanian, proses produksi, pengolahan hasil pertanian, hingga pemasaran produk pertanian. Meningkatkan kapasitas kelembagaan dan memberdayakan SDM pertanian termasuk dalam strategi yang dilakukan Kementrian Pertanian dalam mencapai sasaran swasembada yang lestari, diver- sifikasi pangan, meningkatkan nilai tambah, meningkatkan daya saing ekspor, dan peningkatan kesejahteraan petani (Watemin \& Sulistyani, 2015).Kelompok tani adalah aktor utama dalam pertanian di perdesaan. Keberadaan lembaga kelompok tani menjalankan peran penyediaan input usaha tani semisal pupuk dan bibit, penyediaan modal dengan cara simpan pinjam, serta pemasaran hasil tani secara kolektif.

Faktor yang berpengaruh terhadap kelembagaan petani adalah: dukungan pemerintah, keterlibatan aktif anggota lembaga tani, kemampuan SDM lembaga tani, kekuatan ekonomi lembaga tani, manajemen kelembagaan, sosial budaya masyarakat tani, sarana dan prasarana kelembagaan (Rizki dkk., 2017). Penilaian kondisi SDM petani umumnya berdasarkan tingkat pendidikan, tingkat pendidikan petani Indonesia mayoritas $80 \%$ SD dan SLTP atau yang sederajat (Supanggih \& Widodo, 2013). Pada kenyataannya, tingkat SDM petani sangat berpengaruh terhadap tingkat penerimaan informasi dan adopsi teknologi yang disalurkan pihak penyuluh pertanian. Mereka juga memiliki persepsi negatif terhadap lembaga keuangan formal. SDM petani pada tingkat rendah berdampak pada minimnyapetani yang berminat untuk mengikuti pelatihan pertanian dan sosialisasi pertanian yang diselenggarakan pemerintah, dengan tingkat pendidikan petani masih rendah, petani kurang memahami teori-teori pertanian yang disampaikan dalam sosialisasi (Ahmar dkk., 2016). Akibat selanjutnya mereka belum mampu mengolah pertanian dan hasil pertaniannya dengan optimal.

Dukungan pemerintah dalam pembinaan lembaga tani tertuang dalam Peraturan Menteri Pertanian Republik Indonesia Nomor 67/ PERMENTAN / SM.050/12/2016 tentang Pembinaan Kelembagaan Petani. Program-program bantuan pemerintah dapat diperoleh oleh petani melalui lembaga tani yang memiliki struktur formal dan sanggup mewadahi masyarakat petani. Dengan kondisi ini, 
banyak lembaga tani terbentuk secara pragmatis hanya karena keperluan mengakses anggaran program pemerintah setempat, sehingga fungsi kelembagaan sepenuhnya tidak dipahami dengan baik oleh petani anggota (Rizki dkk., 2017). Anggota dan pengurus lembaga tani juga kurang berperan optimal dalam kelembagaan tani, komunikasi antara pengurus dan petani kurang baik, ditemukan beberapa anggota dan pengurus lebih mengutamakan kepentingan pribadi daripada kepentingan lembaga dan kelompok tani, fasilitas lembaga hanya dimanfaatkan oleh beberapa pengurus untuk pribadi (Rizki dkk., 2017). Fasilitas bersama yang sejatinya untuk anggota tidak dapat dimanfaatkan oleh seluruh anggota dengan baik.

Kekuatan modal yang dimiliki lembaga tani seringkali kalah dengan kekuatan modal tengkulak dan pedagang besar (Santoso \& Darwanto, 2015), dan untuk memperoleh dana, petani lebih bergantung pada para tengkulak daripada lembaga tani karena lebih cepat dan mudah (Sunartomo, 2016). Hasil produksi pertanian masih dikuasai tengkulak karena mereka mampu membayar tunai pembelian hasil pertanian, meskipun petani dirugikan dengan harga tawar yang rendah (Ahmar dkk., 2016). Posisi tawar petani dan kelompok tani masih rendah. Masalah pemodalan lembaga juga berakibat kurang terpenuhi sarana dan prasarana produksi, baik secara kuantitas yang tidak mencukupi kebutuhan maupun kondisi sarana dan prasarana yang rusak dan tidak layak.

Tata Niaga, Produksi Pertanian dan Kebutuhan Komoditas

Karakteristik produksi pertanian mengenal seasonal, puncak produksi terjadi pada musim panen dan produksi pertanian sangat minim di luar periode musim panen. Sementara itu, puncak kebutuhan bahan pertanian terjadi pada periode bulan Ramadhan dan perayaan hari raya (Engkus, 2018). Karakteristik lain dari produk pertanian adalah sifatnya yang mudah rusak jika disimpan lama dan menempati volume yang besar. Karakteristik ini menyebabkan keseimbangan harga permintaan-penawaran selalu berubah sepanjang tahun. Pada musim panen, saat surplus produksi, harga komoditas sangat rendah. Posisi tawar petani rendah dan terpaksa menjual dengan harga rendah akibat petani tidak mampu mempertahankan kualitas produknya jika menahan penjualan untuk mendapatkan harga yang lebih baik. Masalah tata niaga pertanian tidak hanya terjadi pada periode pasca panen, pada masa produksi, petani menghadapi masalah penyedian bibit, pupuk dan obat hama (Santoso \& Darwanto, 2015).

\section{Regulasi Kebijakan Pertanian}

Kebijakan pemantapan ketahanan pangan menjadi isu sentral dalam pembangunan pertanian untuk mencapai stabilitas pangan nasional. Langkah penting yang sudah dilakukan pemerintah adalah reformasi arah pembangunan dengan fokus pada pembangunan sektor pertanian dan pedesaan (Wicaksono, 2012). Pemerintah Indonesia menerapkan kebijakan untuk melindungi kesejahteraan para petanidalam Undang-Undang Nomor 18 Tahun 2012 serta Undang-Undang Nomor 19 Tahun 2013, masing-masing tentang Ketahanan Pangan serta tentang Perlindungan dan Pemberdayaan Petani. Dalam pernyataan Undang-Undang tersebut, produk-produk pertanian lokal harus diprioritaskan oleh pemerintah dalampemenuhan kebutuhan nasional, berlaku larangan impor komoditas pertanian di saat pasokan domestik dinilai mencukupi. Pernyataan Undang-Undang tersebut juga mengatur kewenangan pemerintah dalam menyediakan subsidi pupuk dan benih bagi petani, untuk menurunkan biaya petani dan mencapai tujuan swasembada pangan berkelanjutan (Patunru \& Respatiadi, 2017).

\section{Manajemen Risiko dan Keuangan}

Risiko mengandung pengertian sebagai kemungkinan rugi, ketidakpastian, atau 
probabilitas atas hasil yang tidak sesuai dari yang diharapkan (Wulandari \& Wahyudi, 2014). Risiko pada pertanian terdiri dari risiko pasokan, risiko produksi, risiko pengolahan pasca panen, risiko pemasaran, risiko lingkungan, dan risiko keuangan (Syamsiyah dkk., 2019). Risiko pasokan bersumber dari kualitas dan ketersediaan benih, pupuk dan obat untuk hama penyakit. Risiko produksi berasal dari ketidak-pastian tingkat produksi tani, serangan hama penyakit, kesuburan tanah. Risiko pengolahan pasca panen terkait kualitas produk pertanian, nilai tambah produk, daya simpan dan daya tahan produk. Risiko pemasaran terkait dengan kesimbangan pasokan dan kebutuhan komoditas, harga produk, jangkauan pasar dan distribusi. Risiko lingkungan akibat cuaca yang tidak menentu. Dan risiko keuangan terkait dengan cashflow, permodalan, periode pembayaran.

Kesejahteraan diukur dari kemampuan keluarga untuk mewujudkan indikator sosial, kesehatan, ekonomi, pendidikan, dan kepuasan hidup. Sukmawati dkk. (2020), menunjukkan hubungan antara tata kelola keuangan dari keluarga petani terhadap kesejahteraan keluarga petani, juga dipengaruhi pendapatan petani. Namun tidak lebih dari enam persen petani yang membuat perencanaanbelanja rumah tangga dan menjalankannya secara tertib (Yuwono dkk., 2017). Yuwono dkk. (2017), juga menunjukkan rendahnya tingkat keuangan inklusif, tingkat literasi keuangan, dan tingkat penggunaan layanan produk lembaga keuangan oleh petani Indonesia.

\section{Demografi Sosial Petani Indonesia}

Satu diantara faktor sukses pembangunan pertanian yang lestari adalah sumber daya manusia yang berkomitmen mengembangkan sektor pertanian. Petani saat ini dipandang sebagai obyek pembangunan itu sendiri, bukan subyek pembangunan (Kuntariningsih \& Mariyono, 2014). Andri (2014), menilai bahwa pembangunan yang dilakukan selama ini seringkali mengabaikan kenyataan sebagian besar rakyat Indonesia ber-gantung dari sektor pertanian, dan sebagian besar dari mereka tinggal di desa, sehingga menimbulkan dampak besar pada perubahan struktur ekonomi dan sosial. Perubahan sosial akan menambah keragaman dalam struktur sosial masyarakat desa.

Pembangunan pertanian akhir-akhir ini menghadapi permasalahan serius, petani muda terus berkurang jumlahnya, sementara itu petani usia tua semakin bertambah (Susilowati, 2016). Ayu dkk. (2018), memberikan contoh demografi petani di Sumbawa yang menunjukan pendidikan formal petani $86 \%$ lulusan SD dan $85 \%$ berusia diatas 30 tahun. Diantara sebab-sebab rendahnya minat angkatan kerja muda pada sektor pertanian adalah kurang memberikan jaminan tingkat penghasilan, keberlanjutan dan stabilitas pendapatan, berisiko tinggi serta citra sektor pertanian tidak bergengsi (Susilowati, 2016). Di Jawa Timur, Sunartomo, (2016) menemukan gejala sikap puas dalam mengolah usahatani secara tradisional, berakibat petani terhenti mengembangkan potensinya lebih lanjut. Kuntariningsih \& Mariyono (2014), menyarankan pembuat kebijakan di tingkat nasional dan lokal lebih memperhatikan faktor sosial, ekonomi dan kelembagaan supaya tidak kontra produktif.

\section{Adopsi Teknologi dalam Pertanian}

Teknologi dalam pertanian ibarat pisau bermata dua, di satu sisi dapat meningkatkan produktifitas, di sisi lain ada resiko kerugian sepeti yang diidentifikasi dalam Kuntariningsih \& Mariyono, (2014), yaitu kesuburan tanah menurun, kehilangan bahan organik dalam tanah, sedimentasi tanah, erosi, pencemaran air dan tanah akibat residu pestisida dan bahan kimia berbahaya, gotong royong masyarakat luntur.Petani belajar dari pengalaman tentang suatu inovasi teknologi pertanian dengan mencoba beragam variasi tindakan. Seorang petani berpendidikan rendah kerapkali apatis terhadap inovasi pertanian sebagai akibat pengalaman gagaldalam aplikasi 
inovasi pertanian sebelumnya. Teknologi harus mampu memberikandaya saing (competitiveness), nilai tambah (value added), dan keuntungan (profit/benefit) produk pertanian (Kuntariningsih \& Mariyono, 2014).

Akses teknologi pertanian dan penguasaan teknologi pertanian yang masih lemahmenjadikendalayang dihadapi sektor pertanian (Andriaty \& Setyorini, 2013). Meskipun perkembangan teknologi pertanian atau inovasi pertanian selalu disampaikan dalam forum penyuluhan petani. Sunartomo (2016), dalam surveynya di Jawa Timur menyatakan petani beranggapan diseminasi teknologi pertanian oleh penyuluh tani telah merata, namun $15 \%$ beranggapan diseminasi tyang disampaikan belum sesuai dengan kebutuhan petani. Pendapat sebagian besar petani responden, difusi informasi teknologi usahatani dan kebijakan pemerintah masuk dalam kategori sangat baik. Penyuluh tani bekerjasama instansi terkait telah menginformasikan teknologi yang dibutuhkan oleh petani.Penerapan inovasi teknologi pertanian oleh petani ditentukan pada potensi individu petani dalam mengaplikasikan inovasi, ketersediaan informasi, dan karakteristik inovasi (Andriaty \& Setyorini, 2013).

\section{Isu Kelestarian Lingkungan}

Rivai \& Anugrah (2016), mendiskusikan tentang konsep, implementasi dan komitmen pembangunan pertanian berkelanjutan di Indonesia. Paradigma pembangunan di masa lalu dengan prioritas kemajuan ekonomi telah memberikan dampak kerusakan lingkungan juga masalah sosial. Dinamika permasalahan petani, secara empiris lebih di dominasi aktivitas petani yang tidak ramah lingkungan, sehingga secara ekologis telah mengubah ekosistem di pertanian (Kristiyanto dkk., 2018). Pembangunan berkelanjutan adalah komitmen negaranegara dunia yang harus dilaksanakan. Hakekat pembangunan berkelanjutan adalah pembangunan aspek ekonomi, sosial dan lingkungan secara komprehensif.
Maka dari itu,implementasi pembangunan berkelanjutan harus ter-padu lintas sektoral dan multi disiplin pada tingkat pusat dan atau daerah. Sumber daya alam yang stabil ditunjang sistem sosial yang sehat, menjadi basis modal kegiatan ekonomi. Sementara itu sistem sosial yang tidak sehat cenderung mendorong tindakan merusak kelestarian sumber daya alam. Salah satu penghambat pembangunan berkelanjutan adalah ego sektoral yang menyebabkan pelaksanaan menjadi tersekat (Rivai \& Anugrah, 2016).

\section{Strategi Penguatan Kesejahteraan Petani}

Strategi adalah tujuan jangka panjang dari suatu organisasi, serta pendayagunaan dan alokasi semua sumber daya yang penting untuk mencapai tujuan organisasi (Santoso \& Darwanto, 2015). Strategi-strategi penguatan kesejahteraan petani yang tercakup dalam review ini dirangkum dalam tabel 1 , dan dibahas dalam bagian selanjutnya. Kesejahteraan diukur dari kemampuan keluarga untuk memenuhi indikator sosial, ekonomi, pendidikan, kesehatan dan kepuasan hidup (Sukmawati dkk., 2020)

\section{Intensifikasi Pertanian}

Intensifikasi pertanian adalah usaha meningkatkan hasil pertanian dengan menggunakan berbagai sarana mengolah lahan pertanian yang ada dengan sebaikbaiknya. Hanisah \& Juliana (2015), telah membuktikan bahwa produktifitas usahatani sawit di Kabupaten Aceh Timur lebih baik dengan cara mengendalikan kualitas pemupukan, pengendalian hama penyakit, dan pemanenan. Menurut Prasmatiwi dkk. (2012), menunjukkan bahwa di Lampung Tengah intensifikasi pertanian dapat meningkatkan ketahanan pangan petani padi. Ketahanan pangan suatu rumah tangga diukur dari indikator klasifikasi silang antara pangsa pengeluaran pangan dengan kecukupan energi, sedangkan Intensifikasi pertanian diukur dengan penerapan sapta usahatani. 
Di tempat lain Ihsan dkk. (2016), menunjukan keberhasilan upaya petani meningkatkan produksi padi di Kabupaten Hulu Sungai Selatan, Kalimantan Selatan, dilakukan dengan cara mengolah lahan pertanian menggunakan alat traktordan tajak, pengaturan saluran irigasi, menggunakan jenis bibit unggul cihirang, infari 12 , dan nikongga, menggunakan pupuk urea, ponksa, SP 36, dan organik sesuai aturan, dan pemberantasan hama. Intensifikasi dilakukan dengan cara meningkatkan produktivitas lahan persatuan luas, dengan cara menggunakan teknologi spesifik lokasi, termasuk varietas unggul, pemupukan berimbang sesuai sifat tanah, pengaturan pola tanam (Sudana, 2005).

Intensifikasi pertanian berhasil menaikan produktifitas pertanian, namun di sisi lain penelitian terdahulu menunjukkan intensifikasi pertanian menyebabkan peningkatan erosi, kesuburan tanah menurun, keanekaragaman hayati berkurang
(Hidayati dkk., 2019). Selain itu juga menyebabkan eutrifikasi badan air, pencemaran air dan tanah akibat pupuk kimia dan pestisida berlebih, ancaman kesehatan masyarakat hingga penolakan pasar akibat residu pestisida di makanan, lunturnya kearifan tradisional dan budaya tanaman lokal, serta ketergantungan petani pada industri agrokimia (Rivai \& Anugrah, 2016).

Melihat kelemahan intensifikasi pertanian kemudian muncul pendekatan intensifikasi pertanian dengan sistem yang memadukan dua atau lebih bidang pertanian menggunakan konsep siklus daur ulang biologis antar komoditas pertanian meniru siklus daur ulang alami (Hidayati dkk., 2019). Hidayati dkk. (2019), menunjukan sebuah kasus bagaimana perkebunan sawit yang terpadu dengan peternakan sapi bekerja. Kehadiran sapi liar sebelumnya bersifat hama bagi perkebunan sawit karena merusak struk

Tabel 1

Identifikasi Kondisi, Stakeholder Pertanian, Strategi dan Kinerja Pertanian

\begin{tabular}{|c|c|c|c|}
\hline Kondisi & Stake holder & Strategi & Kinerja \\
\hline Kelembagaan & $\begin{array}{l}\text { Kementrian } \\
\text { pemerintahan pusat }\end{array}$ & $\begin{array}{l}\text { Intensifikasi } \\
\text { pertanian }\end{array}$ & $\begin{array}{l}\text { Peningkatan } \\
\text { produkstifitas }\end{array}$ \\
\hline $\begin{array}{l}\text { Tata niaga, } \\
\text { produksi } \\
\text { pertanian dan }\end{array}$ & $\begin{array}{l}\text { Dinas pemerintahan } \\
\text { daerah (pertanian, } \\
\text { kehutanan, }\end{array}$ & $\begin{array}{l}\text { Ekstensifikasi } \\
\text { pertanian }\end{array}$ & Pengurangan biaya \\
\hline $\begin{array}{l}\text { kebutuhan } \\
\text { komoditas }\end{array}$ & $\begin{array}{l}\text { perkebunan dan } \\
\text { peternakan) }\end{array}$ & Diversifikasi usaha & $\begin{array}{l}\text { Perbaikan kualitas } \\
\text { produk dan jasa } \\
\text { layanan }\end{array}$ \\
\hline $\begin{array}{l}\text { Regulasi } \\
\text { kebijakan } \\
\text { pertanian }\end{array}$ & $\begin{array}{l}\text { Industri demand } \\
\text { komoditas pertanian }\end{array}$ & $\begin{array}{l}\text { Pemasaran dan } \\
\text { rantai pasok }\end{array}$ & $\begin{array}{l}\text { Akses pasar lebih } \\
\text { luas }\end{array}$ \\
\hline $\begin{array}{l}\text { Keuangan dan } \\
\text { manajemen }\end{array}$ & $\begin{array}{l}\text { Industri supply } \\
\text { pertanian }\end{array}$ & $\begin{array}{l}\text { Kemitraan dan } \\
\text { kelembagaan }\end{array}$ & $\begin{array}{l}\text { Kestabilan } \\
\text { keuangan }\end{array}$ \\
\hline $\begin{array}{l}\text { risiko } \\
\text { Demografi sosial }\end{array}$ & $\begin{array}{l}\text { Pedagang komoditas } \\
\text { pertanian }\end{array}$ & $\begin{array}{l}\text { Manajemen risiko } \\
\text { dan keuangan } \\
\text { pertanian }\end{array}$ & $\begin{array}{l}\text { perlindungan asset } \\
\text { dan perlindungan } \\
\text { risiko }\end{array}$ \\
\hline Teknologi & Koperasi petani & $\begin{array}{l}\text { Teknologi tepat } \\
\text { guna, hidroponik, }\end{array}$ & $\begin{array}{l}\text { Kondisi kerja lebih } \\
\text { baik }\end{array}$ \\
\hline $\begin{array}{l}\text { Ekologi } \\
\text { lingkungan }\end{array}$ & $\begin{array}{l}\text { Asosiasi petani } \\
\text { Petani atau kelompok } \\
\text { tani } \\
\text { Lembaga keuangan }\end{array}$ & $\begin{array}{l}\text { aquaponik, } \\
\text { mekanisasi, olah } \\
\text { pasca panen, } \\
\text { teknologi budidaya }\end{array}$ & $\begin{array}{l}\text { Diferensiasi sumber } \\
\text { penghasilan } \\
\text { Kelestarian } \\
\text { lingkungan }\end{array}$ \\
\hline
\end{tabular}

Sumber: Data Primer Diolah, 2021 
tanah dan tanaman. Kemudian dengan peternakan terpadu, sapi ini justru dapat mengendalikan gulma perkebunan sawit dan menyediakan pupuk organik.

\section{Ekstensifikasi Pertanian}

Ekstensifikasi pertanian merupakan usaha peningkatan hasil pertanian dengan cara menambah luasan lahan pertanian baru, misalnya dengan cara membuka hutan dan semak belukar, membuka lahan daerah sekitar rawa-rawa, atau daerah pertanian baru yang belum termanfatkan (Hidayati dkk., 2019). Perluasan lahan linear dengan produktifitas tani, namun perluasan lahan harus memperhatikan kesesuaian lahan dengan jenis tanaman dan menguntungkan petani (Sarasutha, 2002). Pemerintah juga turut berperan terhadap keberhasilan perluasan lahan pertanian. Maharani dkk. (2016), menyatakan bahwa sejak pisang mas Kirana ditetapkan sebagai tanaman hortikultura unggulan Jawa Timur oleh Menteri Pertanian di tahun 2005, ekstensifikasi lahan untuk pisang mas Kirana terus diupayakan oleh pemerintah daerah. Fadhillah (2018), menunjukan dukungan pemerintah untuk ekstensifikasi lahan pertanian bawang di Kabupaten Karanganyar, Jawa Tengah. Untuk komoditas garam, strategi perluasan lahan tambak garam dilakukan di Propinsi Nusa Tenggara Timur yang memiliki masa kemarau jauh lebih panjang dari daerah lain, sekitar 8,5 bulan (Salim \& Munadi, 2016). Untuk komoditas jagung Sudana (2005), menyarankan strategi intensifikasi di daerah Jawa, Madura, Bali dan Nusa Tenggara dan ekstensifikasi lahan jagung di pulau Sumatra, Kalimantan dan Sulawesi. Ekstensifikasi lahan jagung dapat dilakukan dilahan kering, lahan lebak, maupun lahan pasang surut. Ketersediaan lahan untuk pertanian membatasi strategi ekstensifikasi pertanian. Namun inovasi urban farming dapat menjadi alternatif arah perluasan lahan. Pengembangan budi daya tanaman di area urban perkotaan dapat dilakukan secara hidroponik, aquaponik, budi daya sistem vertikal, model taman dinding, dan budi daya dalam pot (Susilowati, 2016).

\section{Diversifikasi Usaha}

Strategi diversifikasi usaha mampu meningkatkan nilai ekonomi perkebunan, mengurangi risiko dan tetap memberikan potensi tingkat keuntungan terhadap petani (Rusdiana \& Praharani, 2015). Junaidi (2020), memberikan contoh potensi diversifikasi perkebunan karet dapat dikelola dengan integrasi ternak sapi, kambing atau lebah madu, tumpangsari dengan tanaman sela kedelai, jagung atau pisang, protein dapat diekstrak dari limbah cair pengolahan lateks, pohon karet tua yang diremajakan dapat sebagai substitusi kayu hutan. Analisis usaha dilakukan oleh Rusdiana \& Praharani (2015), terhadap usaha ternak domba dan tanaman ubi kayu memberikan nilai Benefit to Cost Ratio sebesar 2,7 dan potensi pendapatan Rp 8.414.085/ha/tahun.

Pengembangan agrowisata adalah salah satu strategi diversifikasi pertanian. Menurut Pambudi dkk. (2018), strategi ini memerlukan sinergi stakeholder pemerintah daerah dengan kelompok tani guna mendorong peran serta masyarakat untuk membangun potensi agrowisata. Perubahan dari masyarakat petani menjadi masyarakat desa wisata, membutuhkan proses pembelajaran dan adaptasi tersendiri (Dewi dkk., 2018). Ismawati dkk. (2018), menilai ada potensi konflik dalam pengembangan sebuah kawasan agrowisata, dan mengusulkan pendekatan kearifan lokal sebagai model kepemimpinan penyelesaian konflik. Manfaat dari pengembangan agrowisata adalah menciptakan lapangan kerja baru dan differensiasi sumber pendapatan petani (Pambudi dkk., 2018).

\section{Pemasaran dan Rantai Pasok}

Aktifitas rantai pasok mentransformasikan beragam sumber daya, bahan baku beserta komponen lainnya hingga menjadi barang jadi yang sampaipada tangan konsumen (Swastika \& Sumaryanto, 2013). Dalam penelitian Swastika \& Sumaryanto (2013), rantai pasok beras di propinsi Jawa Barat, Kalimantan Barat dan Kalimantan Selatan dimulai dari petani, gabah didistribusikan 
oleh pedagang gabah ke pabrik penggilingan padi untuk dikeringkan, digiling dan dikemas oleh pabrik, kemudian didistribusikan ke pedagang beras. Riyadh (2018), menunjukkan bahwa penggilingan padi memiliki struktur biaya tinggi karena menanggung biaya transportasi. Sedangkan Swastika \& Sumaryanto (2013), menemukan margin keuntungan dari pengolahan beras oleh pabrik beras sangat kecil, pabrik beras mendapat tambahan pendapatan dari produk sampingan dedak dan menir. Mereka tidak dapat menarik margin yang besar karena intervensi pemerintah dalam sistem perdagangan gabah dan beras. Di sisi lain, intervensi pemerintah dalam sistem perdagangan gabah dan beras berhasil mengendalikan variasi harga beras $\mathrm{di}$ tingkat konsumen.

Optimasi jaringan rantai pasok dapat dilakukan dengan tujuan meminimalkan biaya distribusi komoditas tani. Akhmad dkk. (2020), melakukan strategi klustering Kelompok Usaha petani Garam Rakyat (KUGAR) berdasarkan koordinat lokasi dan kapasitas produksi tiap KUGAR, dengan metode penyelesaian P-Median dibangun kluster-kluster KUGAR di Kabupaten Sumenep, Madura, untuk meminimalkan biaya transportasi pengumpulan garam dari KUGAR ke PT. Garam. Sementara itu studi optimasi rantai pasok komoditas daging sapi dilakukan oleh Mahbubi (2014), dengan pendekatan terintegrasi komponen rantai pasok mulai dari breeder menuju peternak, pedagang atau distributor menuju ke rumah potong hewan, hingga industri daging sapi beserta olahannya dan terakhir ke konsumen akhir rumah tangga dan industri, menggunakan pemodelan sistem dinamis. Mahbubi (2014), menjalankan lima skenario diantaranya adalah kondisi eksisting tanpa perubahan kebijakan, skenario menekan angka kematian anak sapi, skenario menekan angka kematian induk sapi, skenario pemotongan sapi betina produktif, skenario tunda poting selama tiga bulan. Skenario yang berhasil mengelola rantai pasok sapi berkelanjutan adalah menekan angka kematian anak sapi. Untuk mencapai angka kematian rendah, Mahbubi (2014), menyarankan pengembangan pembibitan sapi dan kelembagaan usaha ternak sapi.

Riyadh (2018), menemukan struktur pasar yang dihadapi oleh petani cenderung persaingan pasar tidak sempurna dalam analisis saluran pemasaran komoditas bawang merah, cabai merah, beras, jagung, daging sapi di Sumatera Utara. Riyadh (2018), menyarankan pemasaran komoditas melalui kelembagaan petani didukung pembentukan koperasi unit desa dalam bidang penjualan, pembelian, pengolahan, hingga turut berperan dalam hal pemasaran produk pangan untuk menekan biaya pemasaran dan sekaligus meningkatkan posisi tawar dalam menentukan harga komoditas. Kelembagan petani mampu menjamin ketersediaan komoditas tani sehingga pembeli dapat memperoleh produk pertanian dengan akses mudah dengan kualitas dan kuantitas seperti yang diinginkan dan terjaga kontinuitas pemasaran (Fathurrohman, 2016).

\section{Kemitraan dan Kelembagaan}

Rochdiani \& Suranta (2007), meneliti pola kemitraan usaha bersama petani padi di Kabupaten Subang dengan perusahaan PT. EBI, petani mitra menyediakan tenaga dan lahan untuk proses produksi hingga panen, sedangkan perusahaan mitra PT. EBI menyediakan sarana produksi, bimbingan teknologi pengolahan dan produksi serta pemasaran hasil produksi. Rochdiani \& Suranta (2007), membuktikan beda pendapatan petani setelah dan sebelum kemitraan tidak signifikan, namun petani mandapat manfaat sosial yaitusarana produksi, difusi teknologi, rasa aman dan keterjaminan pasar. Hal ini sejalan dengan temuan penelitian pada kasus petani cabai di Kabupaten Jember oleh Falah dkk. (2018), yang menunjukan alasan petani cabai bermitra adalah menjamin pasar, menumbuhkan kekeluargaan dan ketenangan hati, memperoleh bimbingan 
teknis dan bantuan modal, dekat dengan koperasi serta harapan untuk menambah kapasitas diri.

Pola sub-kontrak dijalankan dalam kemitraan agribisnis antarapetani tebu dengan Pabrik Gula Gempolkrep (Azmie dkk., 2019). Pabrik Gula Gempolkrep memberikan pembinaan, bantuan modal, jaminan pasar, dan bagi hasil, sedangkan petani memberikan tebu sebagai bahan baku PG. Gempolkrep. Kedua pihak sepakat membatasi penggunaan bahan kimia. Keuntungan yang diterima petani untuk satu musim tanam sebesar Rp 188.397.351 per luas lahan garapan 5,53 ha. Pola kerjasama operasional agribisnis dengan sukses dijalankan dalam kemitraan petani cabai di Kabupaten Malang dengan juragan cabai (Yulianjaya \& Hidayat, 2016). Alasan petani menjalin kemitraan dengan juragan cabai karena kebutuhan modal usahatani dapat dipenuhi oleh juragan cabai dengan proses pinjaman modal lebih mudah dibandingkan akses bantuan modal perbankan. Pendapatan usahatani petani mitra mencapai Rp35.100.558/ Ha pada musim tanam 2015/2016 sedangkan pendapatan juragan cabai mencapai Rp4.912.428/Ha. Kendala umum yang dihadapi dalam kemitraan adalah petani kurang memahami konsep yang dikembangkan perusahaan mitra dan batasan kapasitas penyimpanan dan pengolahan yang dimiliki oleh perusahaan mitra (Rochdiani \& Suranta, 2007). Kendala lain yang dihadapi dalam kemitraan yaitu kecurangan salah satu pihak, pembayaran yang sering terlambat (Azmie dkk., 2019)

\section{Manajemen Risiko dan Keuangan Pertanian}

Manajemen risiko adalah upaya untuk menilai, menganalisis, mengevaluasi,serta mengendalikan risiko kegiatan organisasi dengan tujuan memperoleh efektifitas dan efisiensi yang lebih baik (Dewi, 2017). Dari definisi ini, maka langkah proses manajemen risiko adalah mengidentifikasi resiko, mengukur risiko, dan mengendalikan risiko. Diantara metode identifikasi dan pengukuran risiko adalah
Failure Mode and Effect Analysis (FMEA) digunakan oleh Fadhillah (2018), untuk analisis risiko usahatani bawang putih di Kabupaten Karanganyar dan Syamsiyah dkk. (2019), untuk analis risiko usahatani manga di Kabupaten Cirebon. Offayana dkk. (2016), mengidentifikasi sumber risiko pertania terdiri dari risiko akibat hama dan penyakit, risiko akibat tenaga kerja, risiko akibat kualitas bibit. Mitigasi yang dilakukan adalah mendapatkan bibit kualitas baik bersertifikat, pelatihan dan pengembangan SDM tani, pengendalian hama dan penyakit secara terpadu.

Manajemen keuangan petani pada tingkat lembaga KUD di Kabupaten Gianyar, Bali, dipelajari oleh Wahyuningsih dkk.(2017), ditemukan bahwa rasio profitabilitas cukup baik sedangkan rasio likuiditas, rasio solvabilitas, dan rasio aktivitas tidak baik. Saran yang diberikan adalah menambah nasabah baru untuk memperbaiki rasio solvabilitas, peningkatan aktivitas usaha dan menekan pemborosan guna memperbaiki rasio aktivitas, dan memperbaiki rasio profitabilitas dengan meningkatkan profit margin, menambah pendapatan, modal sendiri, dan menurunkan biaya.

\section{Teknologi Tepat Guna}

Teknologi sangat strategis dalam meningkatkan produksi pertanian. Hal itu nampak dari peningkatan produksi beras dalam waktu 35tahun terakhir sebagai dampak penggunaan teknologi yang lebih maju (Utami dkk., 2016). Fatchiya dkk. (2016), mengindentifikasi penerapan inovasi teknologi pertanian di Kabupaten Bogor. Petani di lahan kering intensif menerapkan inovasi tumpang sari serta pengolahan hasil pertanian, dan penerapan inovasi sistem jajar legowo secara intensif di lahan sawah. Terbukti penerapan teknologi pertanian berbanding lurus dengan kondisi ketahanan pangan keluarga petani (Fatchiya dkk., 2016).

Tim Pengabdian kepada Masyarakat, Fakultas Pertanian UGM berhasil menerapkan teknologi tepat guna spesifik lokasi di Kabupaten Bantul pada tahun 
2013 dan 2014. Hasil ubinan demplot selama dua musim bertambah menjadi 7,8 hingga 9,8 ton/Ha pada tahun 2014 dari sebelumnya rata-rata 6,8 ton/Ha (Utami dkk., 2016). Contoh aplikasi teknologi spesifik lokasi adalah menyesuaikan teknik budi daya supaya sesuai dengan kondisi agroekosistem lokal setempat, karena setiap komoditas akan tumbuh optimal pada kondisi tanah, iklim, dan dukungan sosial budaya secara spesifik, sehingga perlu dibentuk sistem produksi secara spesifik pada sawah tadah hujan, sawah irigasi, lahan pasang surut dan lahan kering (Utami dkk., 2016).

Thereser yang dikembangkan Adri \& Refdinal (2018), mampu mengurangi kerugian akibat kehilangan gabah ketika panen. Kuntardjo dkk. (2018), menggunakan mesin-mesin produksi makanan ringan untuk meningkatkan nilai tambah pertanian singkong di Magelang. Zam dkk. (2019), menggunakan teknologi pengemasan cabai untuk memperpanjang masa simpan cabai dan menambah nilai jual cabai di Tana Toraja. Mulasari (2019), mengenalkan pada masyarakat Sosrowijayan Yogyakarta teknologi hidroponik dengan modifikasi media tanam menggunakan bahan buangan sabut kelapa, pecahan batu dan serbuk kayu untuk budidaya sayur skala rumah tangga. Selain teknologi hidroponik, terdapat teknologi aquaponik yang dikenalkan oleh Anjar dkk. (2017), pada masyarakat Kabupaten Pacitan. Teknologi aquaponik memadukan budidaya ikan dan budidaya sayur dalam satu sistem sehingga menghemat tempat produksi sekaligus mengahasilkan dua komoditas tani.

\section{Stakeholder Pertanian Indonesia}

Penerapan strategi-strategi penguatan kesejahteraan petani yang telah dibahas di bagian sebelumnya tidak lepas dari peran serta seluruh stakeholder pertanian Indonesia. Stakeholder ini terdiri dari pemerintah yang diwakili oleh kementerian di pemerintahan pusat hingga dinas pemerintahan daerah yang terkait pertanian, kehutanan, perkebunan dan peternakan (Sunartomo, 2016), industri yang menampung komoditas pertanian, koperasi petani, asosiasi petani (Tutik dkk. 2011), pedagang komoditas pertanian, petani atau kelompok tani, lembaga keuangan (Jayanti \& Muksin, 2016). Pemerintah banyak berperan dalam regulasi pertanian, memfasilitasi kelembagaan petani, intervensi tata niaga beras, insentif pemodalan. Industri dapat berperan seperti yang dicontohkan dalam kemitraan pabrik gula dengan petani tebu. Kelembagaan petani yang kuat dan terampil dalam kewirausahaan juga berperan dalam pemasaran komoditas tani, peningkatan SDM petani, membantu pemodalan petani.

\section{Ukuran Kinerja}

Tabel 2 menyajikan matrik hubungan strategi peningkatan kesejahteraan petani dengan ukuran kinerja yang dapat dicapai. Ukuran kinerja terdiri dari peningkatan produktifitas tani, pengurangan biaya, perbaikan kualitas produk dan jasa, akses pasar lebih luas, kestabilan keuangan dan perlindungan risiko, kondisi kerja lebih baik, differensiasi sumber penghasilan, dan kelestarian lingkungan. Peningkatan produktifitas tani dapat dicapai dengan strategi intensifikasi pertanian, ekstensifikasi pertanian dan penerapan teknologi tepat guna. Pengurangan biaya dapat dicapai dengan strategi pemasaran dan manajemen rantai pasok, manajemen risiko dan keuangan dan penerapan teknologi, namun penerapan teknologi di sisi lain memerlukan biaya investasi. Perlu perencanaan yang tepat untuk startegi penerapan teknologi, intensifikasi, ekstensifikasi dan diversifikasi supaya biaya investasi awal dapat ditutupi oleh peningkatan produktifitas dari intesifikasi, ekstensifikasi dan diversifikasi dan ditutupi oleh penghematan biaya dari penerapan teknologi tepat guna. Perbaikan kualitas produk dan jasa layanan dapat dicapai dari strategi intensifikasi, diversifikasi usaha, pemasaran dan rantai pasok, kemitraan dan kelembagaan, penerapan teknologi. Akses pasar lebih luas didukung oleh 
strategi diversifikasi usaha, pemasaran dan rantai pasok, kemitraan dan kelembagaan, dan penerapan teknologi. Kinerja kestabilan keuangan dan perlindungan risiko didukung oleh strategi pemasaran dan rantai pasok, kemitraan dan kelembagaan, manajemen resiko dan keuangan. Kondisi kerja yang lebih baik bagi petani dapat dicapai dengan strategi Itensifikasi pertanian, kemitraan dan kelembagaan, dan penerapan teknologi (Patent No. EC00201978106, 2019; EC00201978107, 2019). Differensiasi sumber penghasilan dapat dicapai dengan strategi Diversifikasi, kemitraan dan kelembagaan, dan penerapan teknologi. Kelestarian lingkungan didukung oleh strategi kemitraan dan kelembagaan. Penerapan teknologi yang tepat juga mendukung kelestarian lingkungan, namun penerapan teknologi yang tidak ramah lingkungan justru berdampak negatif. Dampak negate terhadap kelestarian lingkungan juga dihasilkan dari strategi intensifikasi dan ekstensifikasi pertanian.

\section{SIMPULAN}

Dapat disimpulkan bahwa strategi-strategi intensifikasi pertanian, ekstensifikasi pertanian, diversifikasi usaha tani, pemasaran dan rantai pasok, kemitraan dan kelembagaan, manajemen risiko dan keuangan, dan penerapan teknologi mampu menguatkan kesejahteraan petani melalui ukuran kinerja produktifitas tani meningkat, penurunan biaya, perbaikan kualitas produk dan jasa, akses pasar lebih luas, kestabilan kuangan dan perlindungan risiko, kondisi kerja lebih baik, differensiasi sumber penghasilan, dan kelestarian lingkungan. Strategi intensifikasi pertanian dapat meningkatkan produktifitas, perbaikan kualitas produk, kondisi kerja petani lebih baik, dan mendukung kelestarian lingkungan. Namun di sisi lain strategi intensifikasi pertanian perlu biaya tambahan dan jika tidak dilakukakan dengan tepat akan berdampak negative terhadap kelestarian lingkungan. Strategi ekstensifikasi pertanian juga meningkatkan produksi pertanian dan memberikan differensiasi sumber penghasilan bagi petani. Namun strategi ini memerlukan biaya investasi tidak sedikit dan dapat berdampak negatif bagi lingkungan. Strategi diversifikasi usaha tani meskipun memerlukan investasi tidak sedikit namun

Tabel 2

Matrik Hubungan Strategi dan Kinerja yang Dicapai

\begin{tabular}{|c|c|c|c|c|c|c|c|c|}
\hline 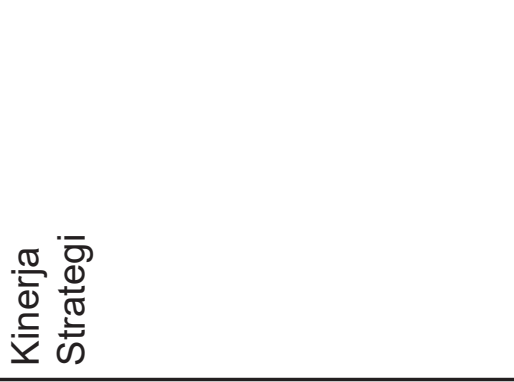 & 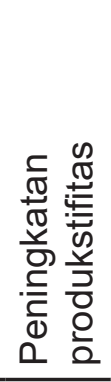 & 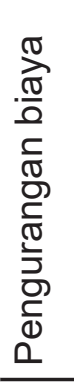 & 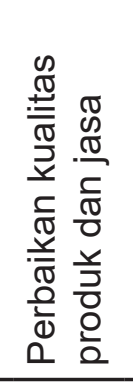 & 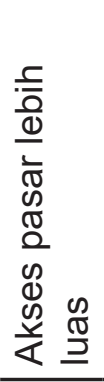 & 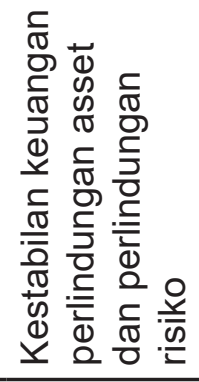 & 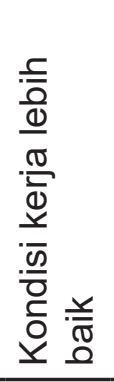 & 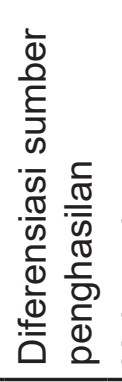 & 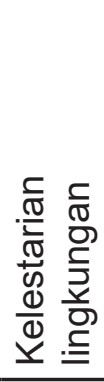 \\
\hline Intensifikasi pertanian & + & - & + & & & + & & \pm \\
\hline Ekstensifikasi pertanian & + & - & & & & & + & - \\
\hline Diversifikasi usaha & & - & + & + & + & & + & \\
\hline Pemasaran dan rantai pasok & & + & + & + & + & & & \\
\hline Kemitraan dan kelembagaan & & & + & + & + & + & + & + \\
\hline $\begin{array}{l}\text { Manajemen risiko dan } \\
\text { keuangan }\end{array}$ & & + & & & + & & & \\
\hline Teknologi & + & \pm & + & + & & + & & \pm \\
\hline
\end{tabular}


mampu memberikan differensiasi sumber penghasilan bagi petani, kestabilan keuangan dan perlindungan risiko, akses pasar lebih luas, dan perbaikan kualitas produk dan jasa. Strategi manajemen pemasaran dan manajemen rantai pasok dapat menurunkan biaya, memperluas akses pasar, kualitas produk dan jasa lebih baik, kestabilan keuangan dan perlindungan risiko. Strategi penguatan lembaga dan kemitraan mampu meningkatkan kualitas produk pertanian, memberikan akses pasar lebih luas, kestabilan keuangan, perlindungan risiko, kondisi kerja lebih baik, differensiasi sumber penghasilan, dan mendukung kelestarian lingkungan. Strategi manajemen risiko dapat menurunkan biaya, menjaga kestabilan keuangan dan menurunkan risiko. Strategi penerapan teknologi tepat guna dapat meningkatkan produktifitas tani, menghemat biaya, memperbaiki kualitas produk pertanian, memperluas akses pasar, memberikan kondisi kerja yang lebih baik bagi petani, dan turut menjaga kelestarian lingkungan. Namun penerapan teknologi tanpa perencanaan yang baik justru menambah biaya dan berdampak negatif terhadap kelestarian lingkungan. Penulis menyarankan prioritas strategi penguatan kelembagaan tani dan kemitraan, karena strategi ini memberikan lebih banyak dampak positif pada kinerja kualitas produk, akses pasar, kestabilan keuangan dan perlindungan risiko, kondisi kerja lebih baik, differensiasi sumber penghasilan dan mendukung kelestarian lingkungan. Strategi penguatan lembaga tani dan kemitraan juga memberikan jalan bagi pelaksanaan strategi penerapan teknologi, strategi intensifikasi pertanian, strategi manajemen pemasaran dan manajemen rantai pasok, serta strategi diversifikasi usaha.

\section{DAFTAR PUSTAKA}

Adri, J., \& Refdinal. (2018). Aplikasi Teknologi Tepat Guna Thereser Multiguna. Jurnal Sains Dan Teknologi, 18(2).
Ahmar, Mappamiring, \& Parawangi, A. (2016). Peran Pemerintah dalam Pemberdayaan Petani Padi di Desa Parumpanai Kecamatan Wasumpoda Kabupaten Luwu Timur. Administrasi Negara, 2(2), 120-136.

Akhmad, S., Arendra, A., Mu'alim, \& Hidayat, R. (2020). The communal salt farmer ventures grouping strategy in Sumenep District using the P-Median method to minimize transport distance in food supply chain network. Journal of Physics, 1477(052063). https://doi.org/10.1088/17426596/1477/5/052063

Andri, K. B. (2014). Profil dan Karakteristik Sosial Ekonomi Petani Tanaman Pangan di Bojonegoro. Agriekonomika, 3(2), 167-179.

Andriaty, E., \& Setyorini, E. (2013). Ketersediaan Sumber Informasi Teknologi Pertanian Di Beberapa Kabupaten Di Jawa. Jurnal Perpustakaan Pertanian, 21(1), 30-35. https://doi.org/10.21082/jpp. v21n1.2012.p

Anjar, A., Petrus, B., \& Gede, S. (2017). Bertanam Sayur dan Beternak Ikan dengan Teknologi Akuaponik. Jurnal Abdikarya, 01(1), 1-3.

Arendra, A., \& Akhmad, S. (2019). Patent No. EC00201978106. Indonesia: Kementerian Hukum dan Hak Asasi Manusia, Republik Indonesia.

Arendra, A., \& Winarso, K. (2019). Patent No. EC00201978107. Indonesia: Kementerian Hukum dan Hak Asasi Manusia, Republik Indonesia.

Ayu, I. W., Sebayang, H. T., Soemarno, S., Prijono, S., \& Iskandar, S. (2018). Analisis Karakteristik Demografi dan Sosial Ekonomi Petani Lahan Kering Iklim Kering di Dusun Brang Pelat, Kecamatan Unter Iwes Kabupaten Sumbawa. Jurnal Riset Kajian Teknologi Dan Lingkungan (JRKTL), 1(2), 70-79. 
Azmie, U., Dewi, R. K., \& Sarjana, I. D. G. R. (2019). Pola Kemitraan Agribisnis Tebu Di Kecamatan Jetis Kabupaten Mojokerto. Agrisocionomics: Jurnal Sosial Ekonomi Pertanian, 3(2), 119-130. https://doi.org/10.14710/ agrisocionomics.v3i2.5062

Barnett, W. P., \& Hansen, M. T. (1996). The Red Queen in Organizational Evolution. Strategic Management Journal, 17(1996), 139-157.

Dewi, I. N., Awang, S. A., Andayani, W., \& Suryanto, P. (2018). Karakteristik Petani dan Kontribusi Hutan Kemasyarakatan (HKm) Terhadap Pendapatan Petani di Kulon Progo. Jurnal IImu Kehutanan, 12(1), 86. https://doi.org/10.22146/jik.34123

Dewi, R. K. (2017). Manajemen risiko dalam usahatani. In Manajemen risiko dalam usahatani. Denpasar, Bali: Universitas Udayana.

Engkus, E. (2018). Implementasi Undang-Undang Perdagangan Dan Implikasinya Dalam Pengendalian Harga Kebutuhan Pokok Masyarakat. Litigasi, 18(1), 1-40. https://doi. org/10.23969/litigasi.v18i1.284

Fadhillah, H. (2018). Analisis Strategi Manajemen Risiko Pada Usahatani Bawang Putih Di Kelurahan Kalisoro, Kecamatan Tawangmangu, Kabupaten Karanganyr Tahun 2018. NCMAB (The National Conference Management and Business) 2018, 190-207.

Falah, H. H., Sudarko, \& Subekti, S. (2018). Persepsi Petani Cabai Besar dan Pengelola Koperasi Terhadap Kemitraan Agribisnis. Jurnal Sosial Ekonomi Dan Kebijakan Pertanian, 7(2), 176-187. Retrieved from
Fatchiya, A., Amanah, S., \& Kusumastuti, Y.I. (2016). Penerapan Inovasi Teknologi Pertanian dan Hubungannya dengan Ketahanan Pangan Rumah Tangga Petani. Jurnal Penyuluhan, 12(2), 190. https://doi.org/10.25015/ penyuluhan.v12i2.12988

Fathurrohman, Y. E. (2016). Model Kerjasama Kelompok Pembudidaya Ikan (Pokdakan) Pada Pemasaran Agribisnis Ikan Gurami Di Kabupaten Banyumas. Agriekonomika, 5(2). https://doi.org/10.21107/ agriekonomika.v5i2.1750

Foss, N. J. (1997). On the Foundations of the Strategic Theory of the Firm: Should We Rely on Governance, Capabilities, or Both?

Grando, S., Bartolini, F., Brunori, G., Prosperi, P., Avermaete, T., Bonjean, I., \& Mathijs, E. (2016). Strategies for sustainable farming: an overview of theories and practices. Inertial Fusion Sciences and Applications, 15. Retrieved from http://www. sufisa.eu/userfiles/update 11122016/ grando et al (2016).pdf

Hanisah, M., \& Juliana. (2015). Pengaruh Mutu Intensifikasi Terhadap Produksi pada Usahatani Kelapa Sawit (Elaeis guenensis, Jacq) Di Kecamatan Sungai Raya Kabupaten Aceh Timur. AGRISAMUDRA, 2(1), 41-50.

Hidayati, F., Yonariza, Y., Nofialdi, N., \& Yuzaria, D. (2019). Intensifikasi Lahan Melalui Sistem Pertanian Terpadu: Sebuah Tinjauan. Unri Conference Series: Agriculture and Food Security, 1, 113-119. https:// doi.org/10.31258/unricsagr.1a15 
Ihsan, G. T., Arisanty, D., \& Normelani, E. (2016). Upaya Petani Meningkatkan Produksi padi di Desa Tabihi Kecamatan Padang Batung Kabupaten Hulu Sungai Selatan. JPG (Jurnal Pendidikan Geografi), 3(2), 11-20.

Ismawati, I., Fitrianti, S., Sillia, N., \& Fauzi, N. (2018). Strategi Pengembangan Taman Wisata Lembah Harau Sumatera Barat Berbasis Kearifan Lokal: Tungku Tigo Sajarangan. Jurnal Sosial Ekonomi Dan Kebijakan Pertanian, 7(2), 176-187.

Jayanti, A. L., \& Muksin, -. (2016). Analisis Stakeholder Dalam Agribisnis Buah Naga Di Kecamatan Bangorejo Kabupaten Banyuwangi. Jurnal Ilmiah Inovasi, 15(3). https://doi. org/10.25047/jii.v15i3.12

Junaidi, J. (2020). Strategi Peningkatan Nilai Tambah Perkebunan Karet Melalui Diversifikasi Usaha. Agriekonomika, 9(1), 72-89. https:// doi.org/10.21107/agriekonomika. v9i1.6928

Kristiyanto, Kristiana, R., \& Sitanggang, N. D. H. (2018). Konservasi Lahan Pertanian Berbasis Ekologi di Kawasan Dataran Tinggi Dieng Wonosobo. Seminar Nasional Edusainstek FMIPA UNIMUS 2018, 108-119.

Kuntardjo, S. B., Suharto, Sarana, \& Paryono. (2018). Program Penerapan Teknologi Tepat Guna Untuk Produksi Makanan Olahan Hasil Pertanian Di Magelang. Prosiding Seminar Nasional Unimus, 1, 673-677. Retrieved from http:// prosiding.unimus.ac.id/index.php/ semnas/article/view/62

Kuntariningsih, A., \& Mariyono, J. (2014). Adopsi Teknologi Pertanian Untuk Pembangunan Pedesaan: Sebuah Kajian Sosiologis. Agriekonomika, 3, 180-191.
Kusmiadi, E. (2014). Pengertian dan Sejarah Perkembangan Pertanian. In Pengantar IImu Pertanian. Retrieved from http://repository.ut.ac.id/4425/1/ LUHT4219-M1.pdf

Lippman, S. A., \& Rumelt, R. P. (1982). Uncertain Imitability: An Analysis of Interfirm Differences in Efficiency under Competition. The Bell Journal of Economics, 13(2), 418-438. https://doi.org/10.2307/3003464

Lippman, S. A., \& Rumelt, R. P. (1992). Demand uncertainty, capital specificity, and industry evolution. Industrial and Corporate Change, 1(1), 235-262. https://doi. org/10.1093/icc/1.1.235

Maharani, A. ., Wibowo, R., \& Hapsari, T. . (2016). Pengaruh Kebijakan Penerapan SPO Terhadap Profitabilitas Pisang Mas Kirana di Kabupaten Lumajang. Agriekonomika, 5(3).

Mahbubi, A. (2014). Program Pengembangan Madura Sebagai Pulau Sapi Prespektif Manajemen Rantai Pasok Sapi Berkelanjutan. Jurnal Agriekonomika, 3(2013), 94-105.

Mc. Williams, A., \& Siegel, D. (2001). Corporate Social Responsibility: A Theory of the Firm Perspective. The Academy of Management Review, 26(1), 117-127.

Michael E. Porter. (1974). Consumer Behavior, Retailer Power and Market Performance in Consumer Goods Industries. The Review of Economics and Statistics, 56(4), 419-436.

Mulasari, S.A. (2019). Penerapan Teknologi Tepat Guna (Penanam Hidroponik Menggunakan Media Tanam) Bagi Masyarakat Sosrowijayan Yogyakarta. Jurnal Pemberdayaan: Publikasi Hasil Pengabdian Kepada Masyarakat, 2(3), 425. https://doi. org/10.12928/jp.v2i3.418 
Nielsen, R. P. (1988). Cooperative Strategy. Strategic Management Journal, 9(5), 475-492. Retrieved from http://www. jstor.org/stable/2485957\%5Cnhttp:// about.jstor.org/terms

Nuraini, C., \& Atmaja, U. (2019). Palm Sugar Agribusiness Development Strategy In Tasikmalaya Regency. Agriekonomika, 8(1), 62. https:// doi.org/10.21107/agriekonomika. v8i1.5029

Nuswardani, N. (2019). Protection and Empowerment of Salt Farmers in Madura. International Conference on Life, Innovation, Change, and Knowledge (ICLICK 2018) Protection, 203(Iclick 2018), 313-316. Advances in Social Science, Education and Humanities Research.

Offayana, G. M., Widyantara, I. W., \& Anggreni, I. G. A. A. L. (2016). Analisis Risiko Produksi Stroberi Pada Ud Agro Mandiri Di Desa Pancasari Kecamatan Sukasada Kabupaten Buleleng. E-Journal Agribisnis Dan Agrowisata (Journal of Agribusiness and Agritourism), 5(1).

Ommani, A. R. (2011). Strengths, weaknesses, opportunities and threats (SWOT) analysis for farming system businesses management: Case of wheat farmers of Shadervan District, Shoushtar Township, Iran. African Journal of Business Management, 5(22), 9448-9454.

Pambudi, S. H., Sunarto, S., \& Setyono, P. (2018). Agro-Tourism Development Strategy in Desa Wisata Kaligono (Dewi Kano) of Kaligesing District of Purworejo Regency. Agriekonomika, 7(1), 85. https://doi.org/10.21107/ agriekonomika.v7i1.3835

Patunru, A. A., \& Respatiadi, H. (2017). Upaya Peningkatan Kualitas Program Perlindungan Sosial bagi Para Pekerja di Sektor Pertanian di Indonesia. Center for Indonesian Policy Studies. Jakarta: CIPS.
Peraturan Menteri Pertanian Republik Indonesia Nomor 67/ PERMENTAN / SM.050/12/2016 Tentang Pembinaan Kelembagaan Petani. , (2016).

Prasmatiwi, F. E., Listiana, I., \& Rosanti, N. (2012). Pengaruh Intensifikasi Pertanian Terhadap Ketahanan Pangan Rumah Tangga Petani Padi di Lampung Tengah. Prosiding SNSMAIP III, (978), 98559.

Rivai, R. S., \&Anugrah, I. S. (2016). Konsep dan Implementasi Pembangunan Pertanian Berkelanjutan di Indonesia. Forum Penelitian Agro Ekonomi, 29(1), 13. https://doi.org/10.21082/ fae.v29n1.2011.13-25

Riyadh, M. I. (2018). Analisis saluran pemasaran lima pangan pokok dan penting di lima kabupaten sumatera utara (analysis of marketing channel of the five essentials and important food in five districts of north sumatera). Jurnal Ekonomi \& Kebijakan Publik, 9(2), 161-171.

Rizki, D. A. W., Soetriono, \& Januar, J. (2017). Strategi Penguatan Kelembagaan Ekonomi Agribisnis Kopi Secara Integratif di Kecamatan Sumber Wringin Kabupaten Bondowoso. Agritrop Jurnal IImuIImu Pertanian, 23-28.

Rochdiani, D., \& Suranta, K. J. (2007). Pola kemitraan antara petani padi dengan pt. e-farm bisnis indonesia dalam meningkatkan pendapatan petani padi. Sosiohumaniora, 9(1), 1-7.

Rumelt, R. P., Kunin, H., \& Kunin, E. (2003). What in the World is Competitive Advantage? (No. Policy Working Paper 2003-105). Los Angeles.

Rusdiana, S., \& Praharani, L. (2015). Peningkatan Usaha Ternak Domba Melalui Diversifikasi Tanaman Pangan: Ekonomi Pendapatan Petani. Agriekonomika, 4(1), 80-96. 
Salim, Z., \& Munadi, E. (2016). Info Komoditi Garam. Jakarta: Badan Pengkajian dan Pengembangan Perdagangan.

Santoso, P. B., \& Darwanto, D. (2015). Strategy for Strengthening Farmer Groups by Institutional Strengthening. Jurnal Ekonomi Pembangunan: Kajian Masalah Ekonomi Dan Pembangunan, 16(1), 33. https://doi. org/10.23917/jep.v16i1.936

Sarasutha, I. G. P. (2002). Kinerja usaha tani dan pemasaran jagung di sentra produksi. Jurnal Litbang Pertanian, 21(2), 39-47.

Sudana, W. (2005). Perkembangan jagung pada dekade terakhir serta peluang pengembangan kedepan. Jurnal Sosial Ekonomi Pertanian, 1-20.

Sukmawati, I., Rizkillah, R., Priyambodo, S., \& Istiaji, B. (2020). Manajemen Keuangan dalam Kesejahteraan Keluarga Petani di Desa Bener Kecamatan Wonosari Kabupaten Klaten ( Financial Management in Farmer's Family Well - Being in Bener Village, Wonosari Subdistrict , Klaten District ). 2(2), 220-229.

Sunartomo, A. F. (2016). Kapasitas Penyuluh Pertanian dalam Upaya Meningkatkan Produktivitas Pertanian di Jawa Timur.Agriekonomika, 5(2). 125-136. https://doi.org/10.21107/ agriekonomika.v5i2.1343

Supanggih, D., \& Widodo, S. (2013). Aksesibitas petani terhadap lembaga keuangan (Studi kasus pada petani di desa Sidodadi kecamatan Sukosewu kabupaten Bojonegoro). Agriekonomika, 2(2), 163-173.

Susilowati, S. H. (2016). Fenomena Penuaan Petani dan Berkurangnya Tenaga Kerja Muda Serta Implikasinya Bagi Kebijakan Pembangunan Pertanian. Forum Penelitian Agro Ekonomi, 34(1), 3555.
Swastika, D. K. S., \& Sumaryanto. (2013). Rantai Pasok Beras di Indonesia (Kasus Provinsi Jabar, Kalbar, dan Kalsel). Pusat Sosial Ekonomi Dan Kebijakan Pertanian. Retrieved from https://pse.litbang.pertanian.go.id/ ind/pdffiles/4-tematik-scm-beras-1. pdf

Syamsiyah, N., Sulistyowati, L., Kusno, K., \& Nur Wiyono, S. (2019). Identifikasi Risiko Usahatani Mangga Dalam Pengembangan Agrowisata Di Kabupaten Cirebon. Sosiohumaniora, 21(1), 11. https:// doi.org/10.24198/sosiohumaniora. v21i1.11062

Tutik, Noor, I., \& Hayat, A. (2011). Peran Stakeholder Dalam Pengembangan Tebu Rakyat. Jurnal Administrasi Publik (JAP), 2(5), 823-829.

Utami, S. N. H., Priyatmojo, A., \& Subejo, S. (2016). Penerapan Teknologi Tepat Guna Padi Sawah Spesifik Lokasi di Dusun Ponggok, Trimulyo, Jetis, Bantul. Jurnal Pengabdian Kepada Masyarakat (Indonesian Journal of Community Engagement), 1(2), 239-254. https://doi.org/10.22146/ jpkm.10610

Wahyuningsih, N. M., Rantau, I. K., \& Yudhari, I. D. A. S. (2017). Analisis Kinerja Keuangan KUD Werdhi Mendala Di Desa Batubulan Kecamatan Sukawati Kabupaten Gianyar. E-Jurnal Agribisnis Dan Agrowisata, 6(1), 142. Retrieved from http://ojs.unud.ac.id/index.php/ JAA

Watemin, \& Sulistyani, B. (2015). Pemberdayaan Petani Melalui Penguatan Modal Kelembagaan Petani di Kawasan Agropolitan Kecamatan Belik Kabupaten Pemalang. Agriekonomika, 4(1), 50-58. 
Wicaksono, A. (2012). Optimalisasi Kepemimpinan Nasional Dalam Melaksanakan Kebijakan Distribusi Pangan Dapat Mewujudkan Ketahanan Pangan Nasional. Agriekonomika, 1(1), 36-46.

Wulandari, S., \& Wahyudi, A. (2014). Manajemen resiko dalam pengembangan pertanian organik di Indonesia. Prosiding Seminar Nasional Pertanian Organik, (18-19 Juni 2014), 51-60. Bogor - Indonesia.

Yulianjaya, F., \& Hidayat, K. (2016). Pola Kemitraan Petani Cabai Dengan Juragan Luar Desa (Studi Kasus Kemitraan di Desa Kucur, Kecamatan Dau, Kabupaten Malang). Habitat, 27(1), 37-47. doi.org/10.21776/ ub.habitat.2016.027.1.5
Yuwono, M., Suharjo, B., Sanim, B., \& Nurmalina, R. (2017). Analisis Deskriptif Atas Literasi Keuangan Pada Kelompok Tani. EKUITAS (Jurnal Ekonomi Dan Keuangan), 1(3), 407. https://doi.org/10.24034/ j25485024.y2017.v1.i3.2400

Zam, W., Ilyas, I., \& Syatrawati, S. (2019). Penerapan Teknologi Pascapanen Untuk Meningkatkan Nilai Jual Cabai Di Tanatoraja. Jurnal Dedikasi Masyarakat, 2(2), 92. https://doi. org/10.31850/jdm.v2i2.407

Zehrer, A. (2009). Service experience and service design: Concepts and application in tourism SMEs. Managing Service Quality, 19(3), 332-349. https://doi. org/10.1108/09604520910955339 